\title{
Classification of mountain soils in a subalpine zone - a case study from the Bieszczady Mountains (SE Poland)
}

\begin{abstract}
The aim of the study was to test the suitability of the 6th edition of Polish Soil Classification (SGP6) in reflecting the typical features of subalpine Bieszczady Mts. soils in comparison with the 5th edition of Polish Soil Classification (SGP5) and the newest version of World Reference Base for Soil Resources (WRB). Five soil profiles located in differentiated in terms of the parent material, topography and vegetation conditions of the natural environment were investigated. On the basis of described morphology and determined properties soils were classified according to different soil classifications. All soils under study were featured by presence of thick A horizons and high content of soil organic carbon accumulated even very deep in the profiles. Some of the mineral topsoil layers were classified as umbric/umbrik horizons. Moreover cambic/kambik horizons were present and in some cases also weak redoximorphic features occurred. The SGP6 enabled to distinguish soils with a thick, organic carbon-rich A horizons as umbrisols, a newly created subtype of grey soils. Furthermore, the soil taxonomic position according to SGP6 was more detailed in relation to the soil trophic status (in case of brown soils) and occurrence of weak redoximorphic features. That was reflected in number of subtypes to which analyzed soils were classified - 4 in SGP6 vs 2 in SGP5.
\end{abstract}

Keywords: Soil classification, mountain soils, WRB, Polish Soil Classification, Carpathian Mountains

\section{INTRODUCTION}

Classification of soils in the mountain areas is more problematic than in the lowlands and highlands, because classification systems were primarily designed for areas, which have higher suitability for agriculture or forestry. Mountain soils have a set of characteristic morphological and physico-chemical properties that make it difficult to apply many of diagnostic criteria. First of all, the following soil features should be mentioned: shallow soil profile, high content of rock fragments, high thickness of A horizons and high content of soil organic matter (Skiba 1998). These features are results of soil development on the cover beds overlying continuous hard rock (Waroszewski et al. 2013) and the impact of relatively severe mountain climate (Skiba 1998; Wasak and Drewnik 2018). The impact of climate, in connection with the influence of mountainous vegetation, determines such a specific properties of soil organic matter (Bäumler et al. 2005; Leifeld et al. 2009) that separate types of soil humus have to be distinguished in the mountain areas (Wasak 2013).
An interesting case are the soils occurring at a relatively low altitude above the sea level, however within the subalpine zone, above the upper timberline in the Bieszczady Mts. The influence of climate on the accumulation of soil organic matter is significant (Skiba et al. 2004; Drewnik 2006), and soils are developed on slope covers typical for the mountainous areas of Central Europe (Skiba et al. 1998; Kacprzak 2003).

The aim of this paper is to test the suitability of the 6th edition of Polish Soil Classification (SGP6; Kabała et al. 2019) in reflecting the typical features of subalpine Bieszczady Mts. soils in comparison with the 5th edition of SGP (2011) and the recent version of World Reference Base for Soil Resources (WRB) classification (IUSS Working Group WRB 2015).

\section{STUDY AREA}

Soils occurring in the subalpine zone of the Bieszczady Mts. (SE Poland) were selected for the study (Figure). The study was conducted at the Orłowicza Pass (profile 1), on Tarnica Mt. (profiles 2 and 3), Połonina Wetlińska Mt. (profile 4) and Wielka Raw- 


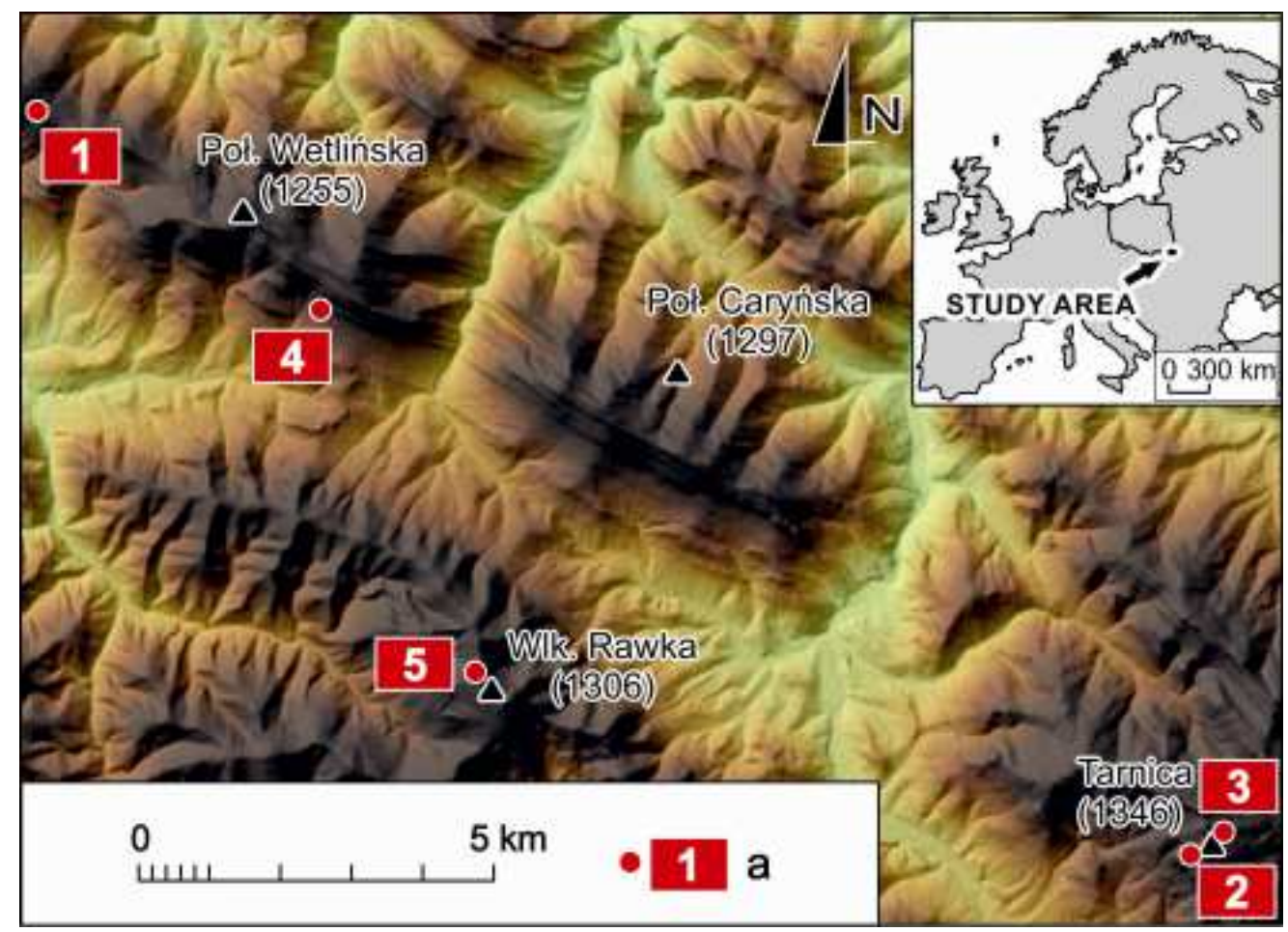

FIGURE. Location of the study area (a - location of the investigated soil profiles)

ka Mt. (profile 5) (Table 1). The Bieszczady Mts. are built of flysch formations comprising of medium to coarse grained sandstones together with thin layers of silt-marl shales or mudstones (Winnicki and Zemanek 2003). The mean annual air temperature (MAAT) in the research area is ca. $4^{\circ} \mathrm{C}$ (Nowosad 1995) - based on data from meteorological station located on Połonina Wetlińska Mt. at the elevation 1230 $m$ a.s.l. As a result of the denivelation of the area, the MAAT is spatially various. The mean annual precipitation (MAP) in the highest parts of the Bieszczady Mts. is 1200-1300 mm (Michna and Paczos 1972). Vegetation in the study area is dominated by $\mathrm{Vacci}$ nium myrtillus $\mathrm{L}$. thickets (profiles $1 \mathrm{C}, 17 \mathrm{C}$ and 22C) or Nardus stricta (profile 1B) and Trollius europaeus L. with Centaurea cyanus L. (profile 19C). Soils in the uppermost parts of the Bieszczady Mts. contain a large amount of rock fragments and low amount of nutrients (usually reflected in low $\mathrm{pH}$ of soils) due to the character of soil parent material (sandstones, mudstones and shales), relief, and humid climate favouring the soil leaching. Also, they have a high concentration of soil organic carbon (SOC) in the uppermost soil horizons. In general terms, Leptosols and Regosols (according to WRB system) prevail near the summits and rock outcrops, while Cambic Leptosols and Dystric Cambisols occur on the slopes (Skiba et al. 1995; 1998).

\section{MATERIALS AND METHODS}

The studied soils were described and sampled according to the Guidelines for Soil Description (Jahn et al. 2006). Soil colour was determined in dry and moist state using Munsell colour charts. Collected samples were air-dried at room temperature (avg. $20^{\circ} \mathrm{C}$ ), gently crushed with a rolling pin, and sieved through a $2 \mathrm{~mm}$ steel sieve. Living roots were removed from the soil samples before further laboratory analyses. All the laboratory analyses were done on the fine earth material (the fraction $<2 \mathrm{~mm}$ ). Soil texture was determined using hydrometer and sieving methods (Gee and Bauder 1986; Van Reeuvijk 2002). Soil $\mathrm{pH}$ was measured potentiometrically in a 1:2.5 soil to distilled water ratio. Soil organic carbon (SOC) content was determined using gas chromatography via varioMICRO cube CHN microanalyzer. Base saturation (BS) was calculated as a ratio of base cations $\left(\mathrm{BC}-\mathrm{Ca}^{2+}, \mathrm{Mg}^{2+}, \mathrm{Na}^{+}, \mathrm{K}+\right)$ measured in the NH4OAc (pH 7) extract (Burt 2004) using AAS to the sum of $\mathrm{BC}$ and exchangeable aluminium (IUSS Working Group WRB 2015). Exchangeable Al was determined by titrating $1 \mathrm{M} \mathrm{KCl}$, unbuffered extract with $0.1 \mathrm{M} \mathrm{NaOH}$ in presence of $3.5 \% \mathrm{NaF}$. 


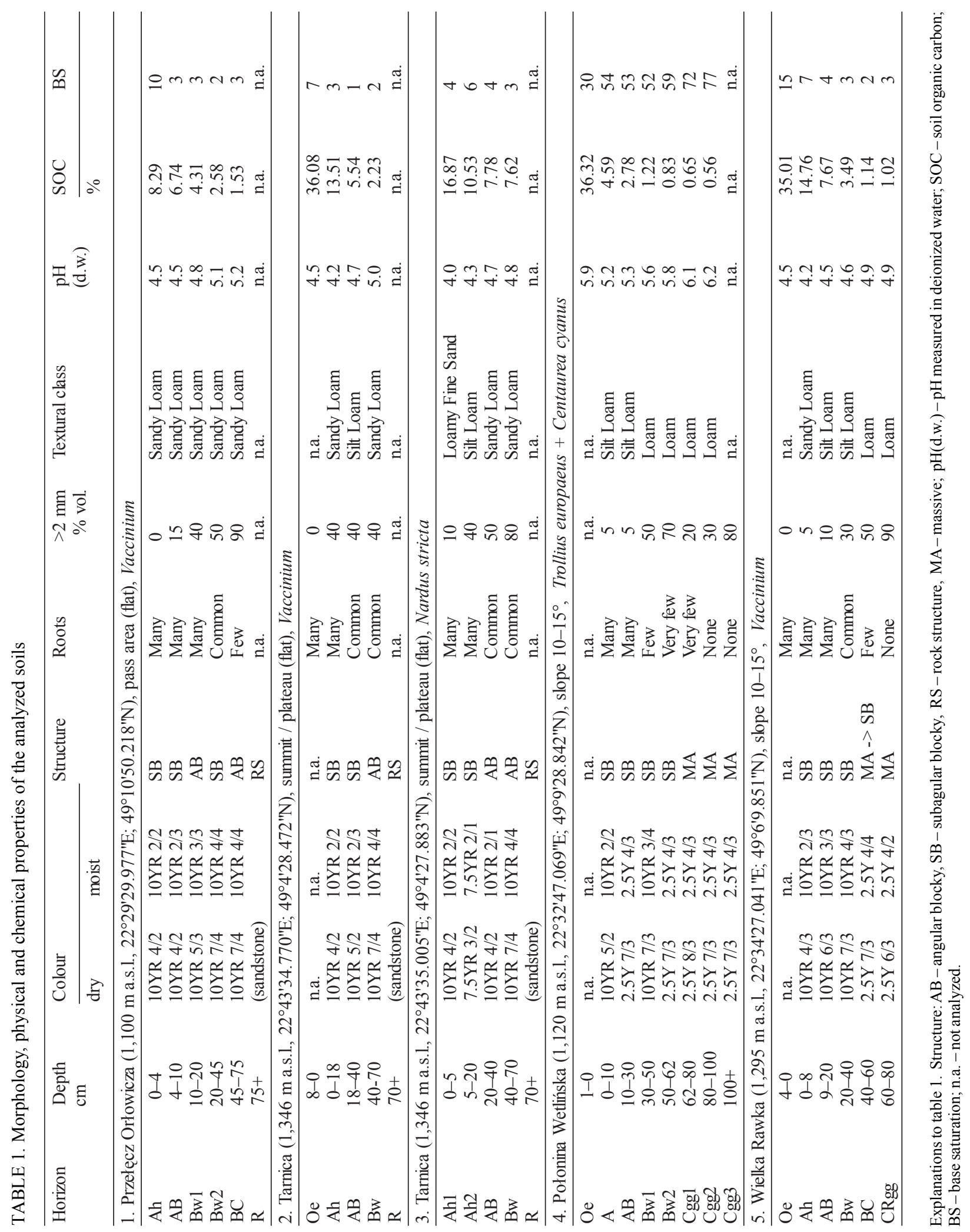




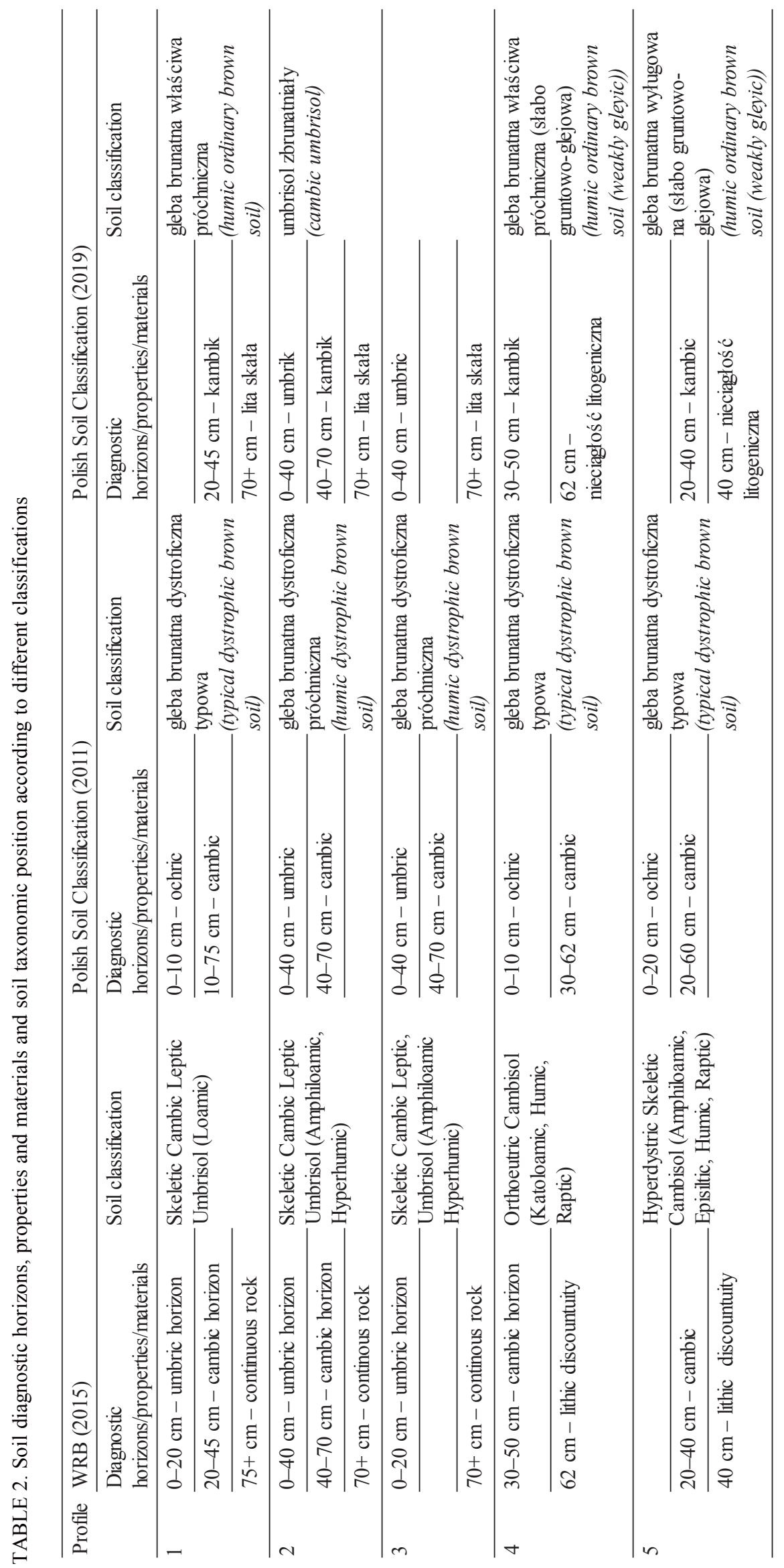




\section{RESULTS}

The studied soil profiles are moderately thick, i.e. the continuous rock occurs at the depth of 70-100 $\mathrm{cm}$. Colour of the soils is mostly yellowish brown (10YR) or yellow (2.5Y). The structure of soils is most often subangular blocky and/or angular blocky. The deepest part of the soils occurring in the Połonina Wetlińska Mt. (profile 4) and Wielka Rawka Mt. (profile 5) is massive structure. Characteristic feature of all the studied soils is an occurrence of abundant roots in the uppermost part of the soil profile 20-40 $\mathrm{cm}$ thick. The content of rock fragments (fraction $>2$ $\mathrm{mm}$ ) increases with depth from $0-5 \%$ in the surface horizons to $80-90 \%$ in the deepest horizons. All of the studied soils are characterized by loamy texture with sandy loam being the most frequent texture class. However, silt loam and loam texture classes are also quite common. Soil reaction of almost all soils (with the exception of soil profile from the Połonina Wetlińska Mt. and covered with Trollio-Centauretum community) is strongly acidic with $\mathrm{pH}$ values ranging from 4.0 to 5.2 . In the soil profile covered with the Trollio-Centauretum community on the Połonina Wetlińska Mt. pH values are slightly higher, ranging from 5.2 in the upper part to 6.2 in the deepest horizon. Soil $\mathrm{pH}$ of the studied soils gradually increases with depth. The SOC content in the mineral horizons of soils under the study ranges from $0.56 \%$ in the $\mathrm{C} 2$ horizon of the soil profile located on the Połonina Wetlińska Mt. (profile 4) to $16.87 \%$ in the Ah1 horizon in the soil profile from Tarnica Mt. (profile 3). OC content is the highest in Oe horizons $(35-36 \%)$. In most of the soils BS is very low (i.e. $<15 \%$ ) and only in one soil covered with Trollio-Centauretum community BS is substantially higher (from $30-52 \%$ in the upper horizons to $59-77 \%$ in the lower horizons).

Based on soil morphology and determined physical and chemical properties, the soils were classified according to WRB as Umbrisols and Cambisols, SGP5 - dystrophic brown soils (gleby brunatne dystroficzne), and according to SGP6 as umbrisols and brown soils (Table 2).

\section{DISCUSSION}

The most characteristic feature of the soils was a presence of thick A horizons and a very high content of SOC accumulated deep in the soil profiles (Table 1). This phenomenon is a typical feature of the soils developed under the influence of humid and cool mountain climate and of these which contain high amount of rock fragments (Migon and Kacprzak 2014). Thick A horizons in the profiles 1, 2 and
3 fulfilled the diagnostic criteria of the umbric horizon (Table 2) and thus were classified as Umbrisols (IUSS Working Group WRB 2015). This is in agreement with reports of other authors (Ganuza and Almendros 2003; Sanesi and Certini 2005; Dümig et al. 2008; Läßiger et al. 2008; Spaargaren 2008), who also showed that Umbrisols are relatively common in the mountains and highlands characterised by humid climate, biomass-rich vegetation and carbonate-free parent material. However, Umbrisols were also reported in the lowlands (Kristiansen and Greve 2003; Świtoniak et al. 2014; Jenčo et al. 2018). Due to more strict criteria of the umbrik horizon implemented in the SGP6 (Kabała et al. 2019), i.e. the required thickness of $\geq 30$ $\mathrm{cm}$, only two topsoil layers (in the profiles 2 and 3 ) met the criteria for umbric horizon. According to the 5th edition of SGP (2011) soils with umbric horizon, but not having murshic properties and having no redoximorphic conditions did not fulfill criteria of any soil type within the black soils (gleby czarnoziemne) order. Hence out of necessity, all the soils with thick and SOC-rich A horizons according to SGP5 were classified as humic dystrophic brown soils (gleby brunatne dystroficzne próchniczne).

The high amount of SOC accumulated to large depth in soils should be considered as a result of both high permeability of regolith (Skiba and Komornicki 1983; Kacprzak et al. 2006) and an effect of increased SOC content in horizon with relatively low content of fine earth fractions (Schaetzl 1991) occurring in soils with high amount of rock fragments. This specific feature of soils under study was reflected by (Hyper)humic qualifier (IUSS Working Group WRB 2015) (Table 1, 2). Neither SGP5 nor SGP6 mark out this feature in the soil names.

Another significant characteristic of the soils was occurrence of subsurface horizons of intensive biochemical weathering - cambic/kambik horizons, common in soils developed from the flysch rocks within the Carpathian Mts. (Skiba 1995). All soils have cambic/kambik horizons (Table 2). Definitions and criteria of cambic/kambik horizons were similar. However, restrictiveness of cambic/kambik horizons criteria, in three classifications compared in this study, were varied. Exclusion of cambic horizon in situation where lithologic discontinuity occurs both above and below the Bw horizon (IUSS Working Group WRB 2015) might affect taxonomic position of some polygenetic soils occurring in mountain areas. On the other hand, more flexible criteria of kambik horizon in SGP6 allow almost all B horizons except the illuvial ones (to be classified as kambik horizon. 
The trophic status of soils is one of the most significant issues in classifying soils. WRB distinguish two basic soil trophic statuses - dystric and eutric based on the base saturation values $(<50 \%$ and $\geq 50 \%$ BS, respectively). All soils, except the profile 4, were classified as dystric (Table 2). In case of the soils classified as Umbrisols this information is already mentioned indirectly in the RSG because the topsoil layer classified as umbric horizon must fulfill the criteria of BS $<50 \%$. Similarly according to the criteria adopted in SGP5 the soils were classified as dystrophic (Table 2); however different method of base cations extraction and also different limit values were implemented in this classification. Thus, according to SGP5 also the soil profile 4 was classified as dystrophic brown soil (gleba brunatna dystroficzna). These criteria were criticized due to inconsistence with soil habitat values (Brożek 2012). In SGP6 (Kabała et al. 2019) all the diagnostic criteria based on BS were substituted by the values of $\mathrm{pH}$ measured in deionized/distilled water. The analysis of the Polish soil database consisting of more than 4500 records made by Kabała and Łabaz (2018) showed a significant correlation between BS and $\mathrm{pH}(\mathrm{w})$. In this study, similarly to the data obtained by Skiba et al. (1998), substantial discrepancies between BS a $\mathrm{pH}$ values were determined. Very complex interactions between the organic matter and specific parent material might be one of the reasons of this disagreement. The high share of clay-rich mineral material might substantially increase BS value of a soil (see profile 4, Table 1). On the other hand, high content of weakly decomposed organic matter, found in soils of mountain areas, might dominate CEC measurement (see profiles 2 and 3, Table 1). Furthermore, $\mathrm{BS}$ value as a quotient might be very sensitive to even very slight measurement errors related to the determination of exchangeable aluminum content. The $\mathrm{pH}(\mathrm{w})$ values in the soils under study are considered to be more relevant than BS values. Thus replacement of $\mathrm{BS}$ value with $\mathrm{pH}(\mathrm{w})$ in terms of classifying soils, proposed by Kabała and Łabaz (2018), is even more justified. Moreover, in case of Brown soils classification a return to a tradition of distinguishing three subtypes referring to the trophic status took place. Thus according to SGP6 the analyzed Brown soils were classified as ordinary (profiles 1,4) or leached (profile 5) (Table 2).

The soils which were developed from mudstones and shales (profiles 4 and 5) showed in its lower parts colours suggesting occurrence of redox depletions
(Table 1). These evidences were, however, insufficient to diagnose gleyic properties according to the criteria of WRB and SGP5. On the other hand, soil varieties (the lowest hierarchical level) implemented in SGP6 allows to reflect such feature in a taxonomic name of soil as weakly gleyic (stabo gruntowo-glejowe) in case of the soil profiles 4 and 5 (Table 2).

\section{CONCLUSIONS}

The suitability of the 6th edition of Polish Soil Classification (SGP6) in classifying mountain soils is much better than the 5th edition (SGP5) and comparable with the results obtained using the World Reference Base for Soil Resources (edition 2015). SGP6 introduced a new soil type - grey soils (gleby szare) with umbrisols (soils with an umbrik horizon) as a subtype. Such soils occurring often in the subalpine zones of Polish mountains were finally properly reflected in Polish Soil Classification. The implemented solution approximates the rules of mountain soils classification in SGP6 and WRB. However, the diagnostic criteria of umbrik horizon in SGP6 are more rigorous (minimal thickness of $30 \mathrm{~cm}$ instead of 20 $\mathrm{cm}$ in WRB) because umbrisols are included into black soils order (gleby czarnoziemne). In result some of the soils classified as Umbrisols in the WRB, but having umbrik horizon thinner than $30 \mathrm{~cm}$ in SGP6 are classified as brown soils (gleby brunatne). Furthermore, the soil taxonomic position according to SGP6 was more detailed in relation to the soil trophic status (in case of brown soils) and weak evidences of reducing conditions. That was reflected in number of subtypes to which analyzed soil were classified - 4 in SGP6 vs 2 in SGP5. Moreover the comparison of SGP6 and WRB classifications revealed also a lack of subtypes/ variety in SGP6 referring to high amount of SOC accumulated deep in soil profiles (humic/hyperhumic qualifiers in WRB) which is also a substantial feature of mountain soils.

\section{ACKNOWLEDGMENTS}

The authors wish to thank the authorities of Bieszczady National Park for for permission to survey the study area and for their overall support. The research was partly funded by the National Fund for Environmental Protection and Water Management (590/2014/ Wn-50/OP-MN/D-2014-2016). 


\section{REFERENCES}

Bäumler R., Caspari T., Totsche K.U., Dorji T., Norbu C., Baillie I.C., 2005. Andic properties in soils developed from nonvolcanic materials in Central Bhutan. Journal of Plant Nutrition and Soil Science 168: 703-713.

Brożek S., 2012. Does Polish Soil Classification, fifth edition, refer to all soils in our country? Roczniki Gleboznawcze Soil Science Annual 63(3): 49-56.

Burt R., 2004. Soil Survey Laboratory Methods Manual. Soil Survey Investigations Report No. 42. Lincoln, NE, USA: USDA-NRCS.

Drewnik M., 2006. The effect of environmental conditions on the decomposition rate of cellulose in mountain soils. Geoderma 132: 116-130.

Dümig A., Schad P., Kohok M., Beyerlein P., Schwimmer W., Kögel-Knabner I., 2008. A mosaic of nonallophanic Andosols, Umbrisols and Cambisols on rhyodacite in the southern Brazilian highlands. Geoderma 145: 158-173.

Ganuza A., Almendros G., 2003. Organic carbon storage in soils of the Basque Country (Spain): the effect of climate, vegetation type and edaphic variables. Biology and Fertility of Soils 37: 154-162.

Gee G.W., Bauder J.W., 1986. Particle?size analysis. [In:] Methods of Soil Analysis, Part 1: Physical and Mineralogical Methods (Klute A, Editor). Soil Science Society of America and American Society of Agronomy, Madison, Wisconsin, USA: $383-411$.

IUSS Working Group WRB, 2015. World Reference Base for soil resources 2014, update 2015. International soil classification system for naming soils and creating legends for soil maps. FAO, Rome, Italy: 203 pp.

Jahn R., Blume H.P., Asio V.P., Spaargaren O., Schad P., 2006. Guidelines for soil description (4th ed.). FAO, Rome, Italy: $110 \mathrm{pp}$.

Jenčo M., Matečný I., Putiška R., Burian L., Tančárová K., Kušnirák D., 2018. Umbrisols at Lower Altitudes, Case Study from Borská lowland (Slovakia). Open Geosciences 10: 121-136.

Kabała C., Łabaz B., 2018. Relationships between soil pH and base saturation - conclusions for Polish and international soil classifications. Soil Science Annual 69(4): 206-214.

Kabała C., Charzyński P., Chodorowski J., Drewnik M., Glina B., Greinert A., Hulisz P., Jankowski M., Jonczak J., Łabaz B., Łachacz A., Marzec M., Mendyk Ł., Musiał P., Musielok Ł., Smreczak B., Sowiński P., Świtoniak M., Uzarowicz Ł., Waroszewski J., 2019. Polish Soil Classification, 6th edition - principles, classification scheme and correlations. Soil Science Annual 70(2): 71-97.

Kacprzak A., 2003. Pokrywy stokowe jako utwory macierzyste gleb Bieszczadów Zachodnich (Slope covers as the soil parent material in the western Bieszczady Mts). Roczniki Gleboznawcze - Soil Science Annual 54(3): 97-110.

Kacprzak A., Drewnik M., Uzarowicz Ł., 2006. Rozwój i kierunki przemian węglanowych gleb rumoszowych na terenie Pienińskiego parku Narodowego (Development and transformation directions of talus carbonate soils in the Pieniny National Park). Pieniny - Przyroda i Człowiek 9: 41-50.

Kristiansen S.M., Greve M.H., 2003. Soil and humus form distribution in the ancient woodland of Hald Ege, Denmark. Danish Journal of Geography 103: 27-36.
Läßiger M., Scheithauer J., Grunewald K., 2008. Preliminary mapping and charactarisation of soils in the Pirin Mountains (Bulgaria). Journal of Mountain Science 5: 122-129.

Leifeld J., Zimmermann M., Fuhrer J., Conen F., 2009. Storage and turnover of carbon in grassland soils along an elevation gradient in the Swiss Alps. Global Change Biology 15: 668679.

Michna E., Paczos S., 1972. Zarys klimatu Bieszczadów Zachodnich. Ossolineum, Wrocław-Warszawa-Kraków-Gdańsk: $72 \mathrm{pp}$.

Migoń P., Kacprzak A., 2014. Lateral diversity of regolith and soils under a mountain slope - implications for interpretation of hillslope materials and processes, Central Sudetes, SW Poland. Geomorphology 221: 69-82.

Nowosad M., 1995. Outlines of climate of the Bieszczady National Park and its buffer zone in the light of previous studies. Roczniki Bieszczadzkie 4: 163-183.

Sanesi G., Certini G., 2005. The umbric epipedon in the N Apennines, Italy - an example from Vallombrosa Forest. Journal of Plant Nutrition and Soil Science 168: 392-398.

Schaetzl R.J., 1991. A lithosequence of soils in extremely gravelly dolomitic parent materials, Bois Blanc Island, Lake Huron. Geoderma 48(3-4): 305-320.

Skiba S., Komornicki T., 1983. Gleby organiczno-sufozyjne w Tatrach (Organic-suffusion soils in the Tatra Mts). Roczniki Gleboznawcze - Soil Science Annual 34(4): 113-122.

Skiba S., 1995. Pokrywa glebowa (Soil cover). [In:] Karpaty Polskie. Przyroda, człowiek i jego działalność (Warszyńska J., Editor). UJ, Kraków: 69-76.

Skiba S., Drewnik M., Drozd J., Klimek M., Prędki R., Szmuc R., Uziak S., Melke J., Chodorowski J., Jała Z., 1995. Mapa gleb Bieszczadzkiego Parku Narodowego. Skala 1:10 000. Uniwersytet Jagielloński - Bieszczadzki Park Narodowy. PPGiK Warszawa, 16 arkuszy.

Skiba S., 1998. Gleby górskie w systematyce gleb Polski. Zeszyty Problemowe Postępów Nauk Rolniczych 464: 25-35.

Skiba S., Drewnik M., Prędki R., Szmuc R., 1998. Gleby Bieszczadzkiego Parku Narodowego (Soils of Bieszczady National Park). Monografie Bieszczadzkie 2, Ustrzyki Dolne: 88 pp.

Skiba S., Drewnik M., Szmuc R., Mazurek R., 2004. Les conditions pedogenetiques d'humiferation des sols dans les regions montagneuses. Prace Geograficzne 113: 53-60.

Spaargaren O., 2008. Umbrisols. [In:] Encyclopedia of Soil Science. Encyclopedia of Earth Sciences Series (Chesworth W., Editor). Springer, Dordrecht.

Systematyka gleb Polski (Polish Soil Classification), 2011. Roczniki Gleboznawcze - Soil Science Annual 62(3): 1-193.

Świtoniak M., Charzyński P., Mendyk Ł., 2014. Forest areas within hummocky moraine plateaus of Poland (Brodnica Lake District). [In:] Soil Sequences Atlas (Świtoniak M., Charzyński P., Editors). Nicolaus Copernicus University Press, Torun: 60-74.

Van Reeuwijk L.P., 2002. Procedures for Soil Analysis. International Soil Reference and Information Centre Technical Paper 9. Wageningen.

Waroszewski J., Kalinski K., Malkiewicz M., Mazurek R., Kozlowski G., Kabala C., 2013. Pleistocene-Holocene coverbeds on granite regolith as parent material for Podzols An example from the Sudeten Mountains. Catena 104: 161173. 
Wasak K., 2013. Zastosowanie wybranych systemów klasyfikacji do określenia typów materii organicznej w glebach leśnych w Tatrach (Application of selected classification systems in describing the types of humus in forest soils of the Tatra Mountains). Prace Geograficzne 135: 101-119.

Wasak K., Drewnik M., 2018. Sequestration of organic carbon in rendzinas: a review. Roczniki Gleboznawcze - Soil Science Annual 69(2): 75-87.
Winnicki T., Zemanek B., 2003. Nature of the Bieszczady National Park. Bieszczady National Park, Ustrzyki Dolne: $176 \mathrm{pp}$.

Received: May 28, 2019

Accepted: August 9, 2019

Associated editor: P. Hulisz

\section{Klasyfikacja gleb górskich piętra subalpejskiego - studium przypadku z Bieszczadów}

Streszczenie: Celem badań była ocena przydatności szóstego wydania Systematyki gleb Polski (SGP6) w odniesieniu do klasyfikacji gleb piętra subalpejskiego Bieszczadów w porównaniu z piątym wydaniem Systematyki gleb Polski (SGP5) oraz najnowszej wersji klasyfikacji World Reference Base for Soil Resources (WRB). Badaniom poddano pięć profili gleb zlokalizowanych w różnicowanych pod względem materiału macierzystego, topografii i roślinności warunkach środowiska przyrodniczego. Na podstawie opisanej morfologii oraz określonych właściwości fizycznych i chemicznych gleby te zostały zaklasyfikowane zgodnie z różnymi klasyfikacjami. Wszystkie badane gleby charakteryzowały się występowaniem miąższych poziomów próchnicznych oraz wysoką zawartością węgla organicznego zakumulowanego nawet do znacznych głębokości. Niektóre z analizowanych poziomów próchnicznych spełniły kryteria diagnostyczne dla poziomów umbric/umbrik. Ponadto badane gleby charakteryzowały się występowaniem poziomów cambic/kambik, a niektóre również słabymi śladami oglejenia. Przeprowadzone badania wykazały większą szczegółowość SGP6 w klasyfikowaniu gleb górskich w porównaniu z poprzednim wydaniem Systematyki gleb Polski oraz porównywalne efekty z zaklasyfikowaniem według klasyfikacji WRB. SGP6 pozwoliła na wyróżnienie gleb z miąższymi i bogatymi w węgiel organiczny poziomami A w randze nowoutworzonego podtypu umbrisoli. Ponadto dzięki zmianom wprowadzonym w 6. wydaniu SGP możliwa jest bardziej precyzyjna klasyfikacja badanych gleb w odniesieniu do ich statusu troficznego (w przypadku gleb brunatnych), a także śladów słabego oglejenia. Różnica szczegółowości SGP6 i SGP5 w klasyfikowaniu badanych gleb górskich przejawiła się w liczbie podtypów, do których zostały one zaliczone - czterech w przypadku SGP6 i dwóch w SGP5.

Stowa kluczowe: Klasyfikacja gleb, gleby górskie, WRB, Systematyka Gleb Polski, Karpaty 